Таран А. Семантичні інновації як вілоьраження суспільно-політичних змін в Україні

УДК 808.3-083-55

DOI https://doi.org/10.24919/2308-4863/34-5-18

Алла ТАРАН,

orcid.org/0000-0001-8091-1477

кандидат філологічних наук,

доиент кафедри украӥнського мовознавства і прикладної лінгвістики

Черкаського національного університету імені Богдана Хмельницького

(Черкаси, Украӥна) alla_taran@ukr.net

\title{
СЕМАНТИЧНІ ІННОВАЦІЇ ЯК ВІДОБРАЖЕННЯ СУСПІЛЬНО-ПОЛІТИЧНИХ ЗМІН В УКРАЇНІ
}

\begin{abstract}
Статтю присвячено дослідженню семантичних змін у сучасній украӥнській номінації, аналізу семантичного потенціалу слова. Семантичні інновачії кваліфікуємо як нове значення в семантиці вже наявного слова.

Аналіз лексеми як мінімальної самостійної мовної структури, ї̈ форми, семантики та функціональних властивостей дає змогу виявити причини й наслідки змін у системі й структурі мови під впливом змін у суспільнополітичному житті, нові когнітивні та комунікативні потреби носїв української мови. Проаналізовано формування нових значень у семантиці слів, досліджено синтагматичні відношення інновацій у системі мови й у тексті, їхню номінаційну та комунікативну активність.

3'ясовано, щео семантичні інновації вносять нові штрихи до украӥнської мовної картини світу, розкривають несподівані смислові зв'язки, які лаконічно концентрують актуальні, сочіально значущі думки. Доведено, щчо контекст - один із обов'язкових чинників, який потрібно враховувати для опису системи лексичного значення слова. Семантичний потенціал слова передбачає участь у таких контекстах і сферах вживання, які здебільшого не характерні для прямого номінативного значення. Важливим мовним чинником зміни семантики вторинних номінацій є протиріччя між формою і змістом, деталізацією номінації й мовною економією, між тенденцією до регулярності і тяжінням до експресії.

Доведено, щзо розвиток семантики слів закінчується або формуванням багатозначності, або виникненням омонімів. Нові контексти вживання й синтаксична сполучуваність сигналізують про появу семантичних відтінків слів (тренер, маніпуляція, хвиля, нафталін / нафталіновий) і формування омонімів (консерва, пороговий). Поява нових семем зумовлює розширення семантичного наповнення слів $i$ засвідчує формування у свідомості українців нових суспільних і мовних стереотипів.
\end{abstract}

Ключові слова: мовна динаміка, суспільно-політичний лексикон, неологізм, семантичні інновації, контекст.

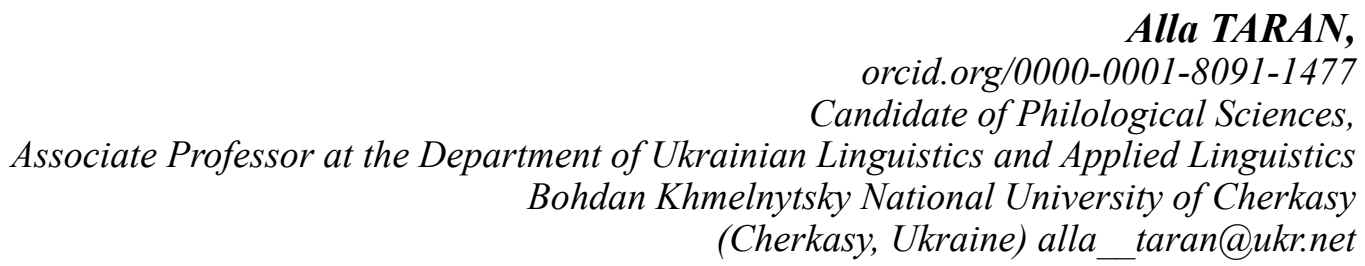

\section{SEMANTIC INNOVATIONS AS A REFLECTION OF SOCIO-POLITICAL CHANGES IN UKRAINE}

The article is devoted to the study of semantic changes in the modern Ukrainian nomination, the semantic potential of the word is analyzed. We qualify semantic innovations as a new meaning in the semantics of an existing word.

Analysis of the word as a minimal independent language structure with form, semantics and functional properties allows to identify the causes and consequences of changes in the language system and structure under the influence of changes in socio-political life, new cognitive and communicative needs of Ukrainian speakers. The formation of new meanings in the semantics of words is analyzed, the syntagmatic relations of innovations in the system of language and in the text, their nominative and communicative activity are investigated. It was found that semantic innovations add new touches to the Ukrainian language picture of the world, reveal unexpected semantic connections that concisely concentrate relevant, socially significant thoughts.

Context has been shown to be one of the mandatory factors to consider when describing a word's lexical meaning system. The semantic potential of a word presupposes participation in such contexts and areas of use that are not usually characterised of direct nominative meaning. An important linguistic factor in changing the semantics of secondary nominations is the contradiction between form and content, the detail of the nomination and language economy, between the tendency to regularity and the tendency to expression. 
It is proved that the development of word semantics ends either with the formation of ambiguity or the emergence of homonyms. New contexts of use and syntactic compatibility signal the emergence of semantic nuances of the word (coach, manipulation, wave, naphthalene / naphthalene) and the formation of homonyms (canned food). At the same time, the appearance of new seeds determines the expansion of the semantic content of words and testifies to the formation of new social and linguistic stereotypes in the minds of Ukrainians.

Key words: language dynamics, socio-political lexicon, neologism, semantic innovations, context.

Постановка проблеми. Особливістю новітнього етапу розвитку української мови є екстралінгвістична детермінантність лексичного збагачення, внаслідок чого відбуваються важливі перетворення, які стосуються не лише кількісних, а й якісних характеристик лексичних одиниць. Якісні зміни в лексиконі визначають не лише номінації з новою формально-семантичною структурою, а й слова, які зазнали певних трансформацій у формі, семантиці, функціональному (експресивно-оцінному) потенціалі.

Виявлення регулярних семантичних переходів, тобто загальних закономірностей розвитку значення, - актуальна проблема для лінгвістів. Термін «семантичний перехід» (semantic shift) в історичному мовознавстві має діахронну специфіку, тобто є свідченням семантичної еволюції. Г. А. Залізняк кваліфікує семантичний перехід як наявність нової концептуальної суміжності між двома мовними значеннями А і В, коли вони пов'язані в одному слові. Водночас семантичний перехід - це, по суті, розширення поняття полісемії через розширення поняття того ж слова.

Як слушно зауважує О. В. Падучева, це не означає, що всі семантичні переходи насправді коли-небудь відбувалися так само, як, наприклад, перехід носового $O$ в $V$ в історії мови. Ймовірно, йдеться про синхронне співвідношення, тобто вмотивованість одного значення іншим. Регулярна багатозначність моделюється як семантична деривація - перехід більш вихідного значення в похідне від нього (Падучева, 2004: 15).

Варто звернути увагу на зв' язок понять «семантична деривація» й «семантичний перехід». Семантична деривація - це прийом опису багатозначності. Для семантичного переходу ключовим $\epsilon$ не правило породження похідного значення, а факт поєднання деяких двох значень в одному слові. Яскравим виявом семантичної перехідності в лексиці є регулярні метафоричні й метонімічні перенесення, термінування й детермінування.

Аналіз досліджень. Проблеми аналізу семантики в різний час і на матеріалі різних мов досліджували В. фон Гумбольдт, Ю. Д. Апресян, В. В. Виноградов, В. А. Звегінцев, Ю. М. Караулов, О. І. Смирницький, Д. М. Шмельов, О. С. Мельничук, В. М. Русанівський, С. Я. Єрмоленко, Н. Ф. Клименко, О. О. Тараненко.
Особливостям оновлення словникового складу української мови в нових умовах іï функціонування в незалежній Україні, зокрема новим лексико-семантичним явищам, присвячено праці Н. Ф. Клименко, Є. А. Карпіловської, Т. А. Коць, Д. В. Мазурик, І. А. Самойлової, О. А. Стишова, Л. В. Струганець, А. М. Нелюби, Ж. В. Колоїз, Н. П. Тропіної та інших вчених. Проблеми семантичної деривації є предметом наукових дискусій російських вчених. Так, спроектовано «Каталог семантичних переходів» і розроблено теоретичні основи семантичної деривації (Г. А. Залізняк, Г. І. Кустова, О. В. Падучева, Р. І. Розіна).

Мета статті - простежити зміни семантики слів, зумовлені суспільно-політичними процесами сьогодення.

Виклад основного матеріалу. Семантичний потенціал слова передбачає участь у таких контекстах і сферах вживання, які здебільшого не характерні для прямого номінативного значення. Важливим мовним чинником зміни семантики вторинних номінацій є протиріччя між формою і змістом, деталізацією номінації й мовною економією, між тенденцією до регулярності і тяжінням до експресії. Передумовою семантичного переосмислення $\epsilon$ зв'язок між словом і денотатом, безпосередній розвиток позначуваного поняття, асоціативне мислення людини. Особливістю вторинної номінації є iï образність і конотативність. Образність має семантичну основу - уявлення, яке відображає двояке бачення явища, коли позначуване асоціюється з іншим предметом за схожістю ознаки, і внутрішню форму, що реалізує в слові метафоричні зв'язки позначуваного з іншим предметом.

Як слушно зауважує В. М. Телія, «вторинна номінація - «додавання готових мовних одиниць до нових образів» або «переосмислення вже наявних у мові номінативних засобів» (Телія, 1996: 117). Вторинна номінація може належати не лише системі мови, а й мовленню. Семантичний ракурс вторинної номінації зумовлений зсувом сем - послабленням архісеми первинного номінативного значення слова 3 одночасним індукуванням оказіональних сем, здатних накладатися на актуалізовані потенційні семи.

Розвиток семантики слів закінчується або формуванням багатозначності, або виникненням омонімів. Яскравим прикладом формування 
Таран А. Семантичні інновації як вілображення суспільно-політичних змін в Україні

переносного значення $€$ іменник маніпуляція, який набув нового спеціального значення в політичному дискурсі. Пересічні носії мови можуть і не здогадуватися про походження цього слова: воно походить від латинського manipulus «жменя», від manus «рука» і pleo «наповнюю» та має пряме значення «складна дія над чимось» і переносне - «махінація» (ЕСУМ, 2006: 383). $\mathrm{y}$ «Словнику іншомовних слів» за редакцією О. С. Мельничука це слово зафіксовано з поясненнями: «1) рухи руки чи обох рук для виконання певного завдання (наприклад, у роботі телеграфним ключем); 2) будь-яка складна дія; 3) переносно - шахрайська витівка». Зі змінами його зафіксовано в пізнішому «Сучасному словнику іншомовних слів» О. І. Скопненка і Т. В. Цимбалюк: «франц. manipulation, manipulus - «жменя» 1. Рух руки або рук, пов'язаний з виконанням певного завдання, наприклад М. лікаря; 2) демонстрування фокусів, яке здебільшого грунтується на вправності рук, умінні відвернути увагу глядачів від того; що має бути від них приховане; 3) перен. Махінації, шахрайські витівки, наприклад М. $з$ цінними паперами» (CCIC, 2006: 433).

Оскільки маніпуляція - це не фізичний вплив на людину, тому іiї об'єктом є психологічні структури, а нове переносне значення - «програмування думок i прагнень мас, їхніх настроїв $\mathrm{i}$ навіть психічного стану для забезпечення такої поведінки, яка потрібна тим, хто володіє засобами маніпулювання. Це мистецтво керувати поведінкою людей за допомогою цілеспрямованого впливу на їхню свідомість та інстинкти» (Руда, 2012: 56). Лексема маніпуляиія розширює сфери використання за рахунок збільшення обсягу семантеми, для якої характерний вищий ступінь узагальнення: маніпуляції в темах, маніпуляції фактами, маніпуляції влади з виборами, тиск $і$ маніпуляцї, договорняки та маніпуляції або Кличко звинувачує Богдана в маніпуляціях (Український тиждень, 2019); Уряд хоче вдвічі знизити обсяг маніпуляцій, фейків і російського контенту (Український тиждень, 2019).

Зміни в денотативному компоненті значення лексеми маніпуляція полягають у втраті кількох диференційних сем і появі сем «суспільно-політичний», «психологічний». Влучно результат розвитку нового значення цієї лексеми визначила Оксана Забужко: «Маніпулятор натискае на кнопки не сильних наших сторін, а слабких. Він користає з гріхів наших. Я ненавиджу людей, які використовують слабкості. Вони знають, щео роблять. Але ті, які ведуться на маніпуляції, відмовляються від раціональності. Вони ведуться на дію підсвідомих імпульсів. Саме ие називається кризою ращіоналізму, яка існує нині» (Газета по-українськи, 2019).

За СУМ-11 лексема маніпулятор - це: «1. Людина, яка робить різні маніпуляції (у 1 знач.); // Цирковий артист-фокусник, який вправно маніпулює різними предметами. 2. Пристрій для передавання телеграфних сигналів. 3. спец. Прилад на пульті управління, у диспетчерській для регулювання складних виробничих процесів» (CУM, IV: 621); у ССІС зафіксовано таке значення «франц. manipulateur, manipulus - 1. Механізм, який під керуванням оператора виконує дії, аналогічні діям руки людини; 2) телеграфний ключ; 3) цирковий артист, ілюзіоніст» (CСIC, 2006: 433). У такому випадку спостерігаємо формування нового значення лексеми маніпулятор «людина, здатна впливати на іншу, яка знає її слабкі місця, впливає на почуття й емоції».

Суспільна цікавість сприяла формуванню нового значення лексеми «консерви». У реєстрах різних українських словників, зокрема в «Словнику української мови» в 11 тт., у «Сучасному словнику іншомовних слів» О. I. Скопненка, Т. В. Цимбалюк зафіксовано такі його значення: «1. Харчові продукти тваринного або рослинного походження, відповідно оброблені (сушінням, стерилізацією, солінням) та вміщені в герметично закриті банки для зберігання протягом тривалого часу. 2. тільки мн., спец. Окуляри з темними скельцями для захисту очей від яскравого світла, пилу. Вживання номінації консерва в окресленій семантико-прагматичній координаті засвідчує живомовний метафоричний контекст: Луценко вважає Ахметова грошовитою "консервою" Януковича. Екс-міністр внутрішніх справ Юрій Луценко назвав Ріната Ахметова "консервою», оскільки той «консервує» гроші на потреби Януковича. Про ие пише «Коммерсантъ» (Український тиждень, 2013). У словнику Л. О. Ставицької «Український жаргон» слово консерва зафіксовано зі значенням «консерваторія» (Ставицька, 2005: 183).

Нині лексема досить активна в сучасній українській мовній практиці, пор. такі контексти вживання у вітчизняних засобах масової інформації: Кого спецслужби називають «консервами». Авантюристка чи «консерва»? Поведінка Савченко після звільнення з російської в'язниці не дає однозначної відповіді на просте запитання: вона - авантюристка чи "консерва" ФСБ (www.dw.com, 2016). "Консерви» Кремля дуже чітко виявляють себе у Польщі - Ганна Гопко (www.radiosvoboda, 2017). Маленькі «консерви» у великій політиці (Еспресо, 2018). ПЕНальті з 
Криму: війна РФ проти Украӥни зриває кремлівські «консерви» в Болгарї (https://novynarnia.com, 2020). Про нові проросійські консерви на міжнародному фронті (Дзеркало тижня, 2020). У cniвавторстві є три намі явні консерви - експерти $і$ дипломати (Український тиждень, 2019). ФСБшні консерви в українській політиці (Еспресо, 2017).

Простежуємо формування омонімічного розвитку семантики слова консерви - «глибоко законспірована агентура, яка протягом багатьох років не демонструє себе, приваблива для оточення, але в час X починає діяти за наказом». У реєстрах нормативних загальномовних словників його ще не зафіксовано.

Структура метафори відома ще з часів Гляйвіцького інциденту. Провокація СС у місті Гляйвіц (операція «Консерви») стала приводом для нападу Німеччини на Польщу в 1939 році. Це була навмисно сконструйована подія, коли офіцери СС, переодягнені в польську військову форму, мали напасти на радіостанцію в Гляйвіці і передати в ефір антинімецьку відозву польською мовою, напасти на лісництво в Пінчені i знищити митний пункт у Хохліндені. Під час нападу німців загинули в'язні концтаборів, тіла яких транспортували на місце подій. На жаргоні трупи називали «консервами».

Серед нових похідних здебільшого натрапляємо на неосемантизми, створені за подібністю до вже наявних слів: «законсервований агент»; "Законсервований» Пукач (Газета по-українськи, 2017); Складається враження, ніби Пукача спеиіально "законсервували" до часу «X», який, вочевидь, настав (Газета по-українськи, 2017).

Для з'ясування значення слів необхідно враховувати контекст, оскільки він може бути засобом відбору й актуалізації значення, засобом синкретизму значень багатозначних слів, засобом формування оказіональних значень, а також засобом додаткового смислового навантаження. Лише в контексті можуть посилюватися ядерні й актуалізуватися периферійні оцінні узуальні семи або реалізуватися потенційні оцінні семи лексем.

Існує певна суперечність між визначенням значення слова через контекст і словникоорієнтованим підходом до визначення значень. Контекст - елемент текстоорієнтованого підходу, а словникоорієнтований підхід передбачає насамперед аналіз дефініцій. Система контекстних ознак у дефініціях не може повністю збігатися 3 контекстними ознаками, зафіксованими в текстах. Тому необхідний спеціальний словник контекстів - словник-конкорданс, де кожне зі значень визначається контекстом.
Г. А. Уфімцева розглядає контекст у такій смисловій парадигмі: «... основні поняття, релевантні для опису лексико-семантичного варіювання, такі: лексико-семантичий варіант слова; семантична структура слова, яка $\epsilon$ ієрархічною системою, історично сформована єдність лексикосемантичних варіантів; системний (мовленнєвий) контекст - обов'язкова умова реалізації віртуального слова; контекстологічний аналіз лексичної семантики, який забезпечує вплив засобів тих рівнів мови, від яких іде вказівка до семантично реалізованого слова» (Уфімцева, 1988: 34-35].

Нові контексти вживання й синтаксична сполучуваність сигналізують про появу семантичних відтінків слова тренер. В етимологічному словнику української мови головною статтею подано дієслово тренувати разом із тренер, треніювання, тренування, тренований, тренувальний, яке засвоєне 3 англійської мови train - «тренувати, виховувати, навчати» (ЕСУМ, 2006: 629). Лексикографічна фіксація слова пов'язана лише зі спортом: «викладач фізичної культури; спеціаліст 3 певного виду спорту, який керує тренуванням спортсменів» (CCIC, 2006: 685); «фахівець, який керує тренуванням спортсменів із певного виду спорту» (СУМ, Х: 245). Проте мікроконтексти вживання слова засвідчують, що воно зазнало розширення значення: «тренер здійснює навчальнотренувальну діяльність, спрямовану на виховання, навчання й удосконалення майстерності, розвиток функціональних можливостей своїх підлеглих». Пор.: тренер із продажу, бізнес-тренер, тренер у сфері залучення роботи з волонтерами, експерти-тренери, тренер-фасилітатор, тренери у сфері земельних правовідносин, тренер у сфері закупівель, тренер/ка з питань протидіі та запобігання домашньому та тендерно зумовленому насильству, мотивачійний тренер.

Розширення значення набуває й лексема хвиля, яка за СУМ-11 має такі значення: «1. Водяний вал, який утворюється від коливання водної поверхні; 2. чого, перен. Нестримне піднесення, посилений рух, вияв чого-небудь. // Наплив почуттів, думок, які визначають настрій людини. 3. фіз. Коливальний рух у фізичному середовищі» (СУМ, XI: 40). В енциклопедичному словнику-довіднику за ред. Н. М. Хоми зафіксовано словосполуку хвилі мобілізаиії із поясненням «етапи планомірного переходу держави на функціонування в умовах особливого періоду та воєнного часу, яких згідно із Законом України «Про мобілізаційну підготовку та мобілізацію» може бути чотири: перші три X. м. зараховують до часткової, а четверту - до повної мобілізації. В умовах неоголошеної війни на Сході 
Таран А. Семантичні інновації як вілображення суспільно-політичних змін в Україні

України в країні у 2014 році була оголошена часткова мобілізація та відбулися три ії хвилі. Враховуючи загострення ситуації, президентським указом передбачене проведення у 2015 році ще трьох X. м.» (Новітня політична лексика, 2015: 307).

Формування в семантиці лексеми хвиля значення «про будь-яке явище в житті суспільства, яке виникає періодично 3 великою силою; про масовий вияв чогось» відображає словосполучення нова хвиля про представників нового напряму в чомусь: перша хвиля еміграції - зі Східної Галичини до Канади в кінці XIX - на початку XX ст.; друга хвиля еміграиії - між Першою і Другою світовими війнами - еміграція наукової і творчої інтелігенції; третя хвиля еміграції - наприкінці Другої світової війни, коли емігрували колишні військовополонені, яких сталінсько-беріївський режим вважав зрадниками; четверта хвиля еміграиї̈ - $з$ кінця 1990-х років («заробітчанська»).

Чи не найактивніше 2020 року функціонує словосполука хвиля коронавірусу: Зеленський: перша хвиля коронавірусу в Україні лише зараз (Українська правда, 2020); Восени COVID-19 повернеться знову $\boldsymbol{i}$ друга хвиля стане більш масштабною, а значить страшнішою. «Примара» осінньої хвилі стала лякаючою (Українська правда, 2020); Tpems хвиля коронавірусу можлива наприкінці зими (Українська правда, 2020). 3'явилася й усталена словосполука «зелена хвиля" - режим роботи світлофорів, який дозволяє рівномірно рухатися 3 певною швидкістю без зупинок на червоне світло: «Зелена хвиля» для світлофорів у Києві розрахо-

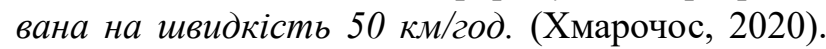

Зазнає змін семантичний потенціал слова нафталін і похідних від нього прикметників нафталінний / нафталіновий. За СУМ-11 нафталін-«біла кристалічна речовина з різким запахом, вживана для боротьби з комірними кліщами, довго- носиками, для охорони вовняних виробів іхутра від молі, а також у техніці й медицині» (СУМ, V: 224), а нафталінний / нафталіновий - прикметник до нафталін. Проте тип мовного повідомлення й контексти реалізують значення «який відійшов у минуле, неактуальний»: Ці витягнуті з нафталіну політики не відображають думок суспільства (Газета по-українськи, 2020); Можна набрати старих чиновників з уряду Януковича, назвати їх новими, але коли під виглядом нових облич підсовують старий нафталін $і$ до того ж часто антиукраӥнський, мене ие відверто насторожує (Газета по-українськи, 2019); Ющенко: Медведчук - ие політичний нафталін (24 канал, 2020); Призначення іноземних «нафталінових» політиків-реформаторів на керівні посади в Україні - це приниження країни (UA 112, 2016); Денисов: «Позбавтеся від дудок. Це нафталіновий пережжиток минулого» (відомий футболіст про підтримку вболівальників у стилі 90-х) (sport. uа, 2020); I вже зовсім суб'єктивно, пане Гриценко, для чого Вам такі пропахлі нафталіном соратники? (zaxid.net, 2018); Нафталіновий Кравчук представлятиме Україну в ТКГ (Газета по-українськи, 2019); Невдоволені коалічіанти кажуть, що Янукович повертається в нафталіновий період (Газета по-українськи, 2010). Результат дії контексту й мовленнєвої ситуації - негативний емоційно-оцінний відтінок лексем.

Висновки. Отже, потужним способом оновлення суспільно-політичного лексикону є неосемантизація. Активне функціонування семантичних інновацій засвідчує формування у свідомості українців нових суспільних і мовних стереотипів. Досліджуючи вияви динаміки мови й семантичні зміни, мовознавці мають з'ясовувати й чинники збереження певних складників мовної системи та продуктів мовної діяльності суспільства.

\section{СПИСОК ВИКОРИСТАНИХ ДЖЕРЕЛ}

1. Вплив суспільних змін на розвиток української мови : монографія / відп. ред. Є. А. Карпіловська. Київ : Видавничий дім Дмитра Бураго, 2017. 444 с.

2. Етимологічний словник української мови: у 7 т. / гол. ред.: О. С. Мельничук. Київ : Наукова думка, 2006. T. $5.703 \mathrm{c}$.

3. Зализняк А. А. Семантический переход как объект типологии. Вопросы языкознания. 2013. № 2. С. 32-51.

4. Земская Е. А. Активные процессы современного словопроизводства. Русский язык кониа ХХ столетия (19851995). Москва : Языки русской культуры. 2000. С. 90-141.

5. Новітня політична лексика (неологізми, оказіоналізми та інші новотвори) / за заг. ред. Н. М. Хоми. Львів : Новий Світ-2000, 2015. 492 с.

6. Падучева Е. В. Динамические модели в семантике лексики. Москва : Языки славянской культуры, 2004. 608 с.

7. Пауль Г. Принципы истории языка. Москва, 1960.500 с.

8. Роль человеческого фактора в языке: язык и картина мира / Б. А. Серебренников, Е. С. Кубрякова, В. И. Постовалова, В. Н. Телия, А. А. Уфимцева. Москва : Наука, 1988. 216 с.

9. Руда О. Г. Мовне питання як об’єкт маніпулятивних стратегій в сучасному українському політичному дискурсі. Київ : Інститут української мови НАН України, 2012. 232 с.

10. Словник української мови: у 11 т. / гол. ред. І. К. Білодід. Київ : Наукова думка, 1970-1980. 
11. Ставицька Л. О. Український жаргон : словник. Київ : Критика, 2005. 496 с.

12. Сучасний словник іншомовних слів / укл. О. І. Скопненко, Т. В. Цимбалюк. Київ : Довіра, 2006. 790 с.

13. Телия В. Н. Русская фразеология. Семантический, прагматический и лингвокультурологический аспекты. Москва : Школа «Языки русской культуры», 1996. 288 с.

14. Ульманн С. Семантические универсалии. Новое в лингвистике. Вып. V: Языковые универсалии. Москва : Прогресс, 1970. С. 250-299.

\section{REFERENCES}

1. Karpilovska Ye. A. Vplyv suspil'nykh zmin na rozvytok ukrayins'koyi movy [Influence of social changes on the development of the Ukrainian language]. 2017, 444 p. [in Ukrainian].

2. Etymolohichnyy slovnyk ukrayins'koyi movy: V 7-y t. [Etymology dictionary of Ukrainian language]. T. 5. 2006, 703 p. [in Ukrainian].

3. Zaliznyak A. A. Semanticheskiy perekhod kak ob’yekt tipologii [Semantic transition as an object of typology]. Linguistics' questions. 2013. № 2. P. 32-51 [in Russian].

4. Zemskaya E. A. Aktivnyye protsessy sovremennogo slovoproizvodstva. [Active processes of modern words production]. Russian language of the late twentieth century (1985-1995). 2000, p. 90-141 [in Russian].

5. Khoma N. M. Novitnya politychna leksyka (neolohizmy, okazionalizmy ta inshi novotvory). [New political vocabulary (neologisms, occasionalism and new lexemes)]. 2015, 492 p. [in Ukrainian].

6. Paducheva Ye. V. Dinamicheskiye modeli v semantike leksiki. [Dynamic models in lexis semantic]. 2004.608 s. [in Russian].

7. Paul G. Printsipy istorii yazyka. [Principles of the History of Language]. 1960, 500 p. [in Russian].

8. Rol' chelovecheskogo faktora v yazyke: Yazyk i kartina mira [A role of human factor is in language: Language and picture of the world] / of B. A. Serebrennikov, E. S. Kubriakova, V. I. Postovalova, V. N. Teliya, A. A. Yfymceva. 1988,216 p. [in Russian].

9. Ruda O. H. Movne pytannya yak ob'yekt manipulyatyvnykh stratehiy u suchasnomu ukrayins'komu politychnomu dyskursi [The language question as an object of manipulative strategies in modern Ukrainian political discourse]. $2012,232 \mathrm{p}$. [in Ukrainian].

10. Slovnyk ukrayins'koyi movy: V 11-y t. (1970-1980). [Dictionary of the Ukrainian language: in the 11th volumes]. [red.: I. K. Bilodid (chairman) and others]. [in Ukrainian].

11. Stavyts'ka L. Ukrayins'kyy zharhon. [Ukrainian jargon: vocabulary]. 2005. 496 p. [in Ukrainian].

12. Suchasnyy slovnyk inshomovnykh sliv [Modern Dictionary of Foreign Words]. [red. O. I. Skopnenko, T. V. Tsymbalyuk]. 2006. 790 p. [in Ukrainian].

13. Teliya V. N. Russkaya frazeologiya. Semanticheskiy, pragmaticheskiy i lingvokul'turologicheskiy aspekty. [Russian phraseology. Semantic, pragmatic and linguocultural aspects]. 1996, 288 p. [in Russian].

14. Ulmann S. Semanticheskiye universalii. [Semantic universalies: Trudged. with an eng // New in linguistics]. Prod. V: Language universalies. 1970. P. 250-299 [in Russian]. 